\title{
Stock market implications of Fed's balance sheet size
}

\author{
Asif M. Ruman \\ Department of Accounting, Economics and Finance, University of Oulu, \\ Oulu, Finland
}

\begin{abstract}
Purpose - Considering the relationship between the central bank balance sheet and unconventional monetary policy after the 2008 financial crisis, it is crucial to see how the unconventional monetary policy, given near-zero interest rates, affects future stock market performance. This paper analyzes the impact of the Fed's balance sheet size on stock market performance.

Design/methodology/approach - To analyze the Fed's balance sheet size's long-term stock market implications, this paper uses the asset pricing framework of market return predictability such as Ordinary least squares (OLS) and Generalized method of moments (GMM) analysis.

Findings - Findings in this paper suggest that the Fed's balance sheet size, deflated by asset market wealth, presents evidence of return predictability during 1926-2015 that is robust against standard controls. These results can be explained through the redistribution of risk and the wealth channels of monetary policy transmission. The changing balance sheet size of a central bank (1) affects systemic risk, yields and expectations and (2) signals the future direction of monetary policy and thus economic outlook.

Research limitations/implications - The main implication of these findings is that policymakers should avoid a severe imbalance between a central bank's balance sheet size and assets market wealth.

Originality/value - The empirical evidence in this paper documents a century-old relation between the Fed's balance sheet size and US stock market return using the Fed's balance sheet data for the last 100 years and stock market returns from the Center for research in security prices (CRSP) database.
\end{abstract}

Keywords Fed's balance sheet, Financial crisis, Quantitative easing, Return predictability, Stock market wealth, Unconventional monetary policy

Paper type Research paper

\section{Introduction}

Under the new Keynesian theory framework, a central bank can influence the real interest rate, real output and nominal prices (Bjørnland and Leitemo, 2009). The main objectives of exerting influence on real interest rates include (1) maintaining a low inflation level and keeping production at a near natural rate. (2) Moreover, a monetary policy is likely to influence stock prices through the interest rate channel as well as through its influence on the determinants of dividends and premiums on stock return by influencing the degree of uncertainty faced by agents (Bjørnland and Leitemo, 2009). (3) Since a central bank affects the monetary policy using various tools, the Fed has a variety of monetary policy tools, including open-market operations, discount rate and reserve requirements [1] (Adrian and Shin, 2009) (4) interest on required reserve balances and excess balances, (5) overnight reverse repurchase agreement facility, (6) term deposit facility and (7) expired policy tools are available on https://www.federalreserve.

\section{JEL Classification - E50, E58, G01, G12}

(C) Asif M. Ruman. Published by Emerald Publishing Limited. This article is published under the Creative Commons Attribution (CC BY 4.0) licence. Anyone may reproduce, distribute, translate and create derivative works of this article (for both commercial and non-commercial purposes), subject to full attribution to the original publication and authors. The full terms of this licence may be seen at http:// creativecommons.org/licences/by/4.0/legalcode

This work greatly benefited from the useful comments from J. Perttunen, A. Arslan, J-P. Kallunki, M. Puhakka, A. Serletis, W. Barnett, P. Pikkarainen, A. Goyal and colleagues at Oulu University's Business School.
Received 3 September 2020 Revised 2 December 2020 18 January 2021 21 January 2021 Accepted 22 January 2021 
JES

49,2

gov/monetarypolicy/policytools.htm. A body of literature focuses on how monetary policy tools and the overall economy affect each other and stock markets (Patelis, 1997; Bordo and Jeanne, 2002; Thornton, 2006; Borio and Drehmann, 2009; Joyce et al., 2011; Billi and Vredin, 2014; Woodford, 2016; Alexius and Sp, 2018; Cieslak, 2018).

After the 2008 financial crisis, central banks aggressively increased their balance sheets, known as quantitative easing (QE) (Reis, 2016). That prompted researchers to study this unusual monetary policy, mostly focusing on the 2008 financial crisis or the economic effectiveness of the unconventional monetary policy (Adrian and Shin, 2009; Gambacorta et al., 2014; Chen et al., 2016; Al-Jassar and Moosa, 2019). Any change in monetary policy using, e.g. open market operations, should also affect the assets and liabilities of a central bank. If the change in any tool of monetary policy is, even partially, reflected in the total assets or liabilities of a central bank, the changing balance sheet size may carry useful signals about changing monetary policy. For example, Curdia and Woodford (2011) use the balance sheet of a central bank as a monetary policy tool. Greenwood et al. (2016) explain that central banks influence relative yields on safe claims by changing the overall supply of safe shortterm claims. This affects the front end of the yield curve. Therefore, the effect of yield changes is also visible in changing the balance sheet size of a central bank.

Thus, the interaction of monetary policy tools and change in the balance sheet size of a central bank should carry useful information for stock markets. Previous research has largely ignored this potential relation until the great financial crisis (see, e.g. Lima et al., 2016; Nakazono and Ikeda, 2016; Al-Jassar and Moosa, 2019; Bedikanli, 2020). To fill this literature gap, I investigate the relation between the Federal Reserve's balance sheet size and stock market return. I use Center for research in security prices (CRSP) and Federal Reserve Archival system for economic research (FRASER) databases during 1926-2015 and follow the asset-pricing literature (Dotsey, 1998; Ang, 2012; Cieslak et al., 2015) to analyze potential market return predictability by the Fed's balance sheet size deflated by asset market wealth (FAMC). FA stands for the Fed's total assets that measure the Fed's balance sheet size, and MC stands for CRSP market capitalization that measures asset market wealth.

This paper's empirical evidence contributes to the literature that focuses on central banks' balance sheet expansion and stock prices (e.g. Lima et al., 2016; Nakazono and Ikeda, 2016; AlJassar and Moosa, 2019; Bedikanli, 2020). Specifically, this paper documents a century-old relation between US Central Bank's balance sheet size and stock market performance. The Fed's balance sheet size deflated by assets market wealth (Fed assets to market cap [FAMC]) predicts future market return during 1926-2015. This predictive power is robust against different sample periods, data frequencies and predicting horizons. Return predictability of FAMC successfully withstands control variables such as (1) relative short-term treasury rate, relative short-term treasury rate (RREL), (2) term spread, (3) inflation, (4) dividend payout ratio, (5) aggregate dividend yield (6) aggregate earnings yield, (7) aggregate industrial production, (8) year fixed effects and (9) potential outliers such as historical bubbles and crashes, e.g. 1930-1931, 1974, 1987, 2000, 2008, etc.

This relation can be explained through the wealth channel of monetary policy transmission. Given the zero lower bound, central banks used "unconventional monetary policy" focusing on maturity transformation and changing the supply of safe assets within their balance sheets (Bedikanli, 2020). Notice that an increase in the Fed's balance sheet size compared to asset market wealth signals an aggressive expansionary monetary policy. An expansionary monetary policy improves macroeconomic indicators and economic outlook. Stock market participants adjust to the improved economic outlook and that increases the asset market wealth. Thus, a positive change in FAMC due to the expansionary monetary policy increases agents' wealth, leading to increased aggregate consumption (Ludvigson and Steindel, 1998). This increased consumption leads to better future economic performance and higher future expected return. 
These findings' main implication is that central banks and regulators should seek to avoid a severe imbalance between a central bank's balance sheet size and asset market wealth. Moreover, this long-term relationship supports the concern discussed by, e.g. Bedikanli (2020) that Fed's open market interventions after 2008 could affect long-term equilibrium in stock markets causing stock prices to deviate too much from their fundamental values and potentially generate too much dependence on central banks' interventions. The rest of the paper is structured as follows. Sections 2, 3 and 4 present the literature, methods and a discussion on the monetary policy transmission mechanism. Lastly, sections 5 and 6 present empirical results, robustness checks and economic significance.

\section{Background literature}

Following the bankruptcy filing by Lehman Brothers, global financial markets crashed. The US Government responded with the $\$ 700$ bn Troubled Assets Relief Program, TARP (Brunnermeier, 2009). The 2008 financial crisis prompted the US Central Bank to operate beyond its traditional dual mandate of stabilizing price levels and employment levels (Greenwood et al., 2016) and start a series of QE programs using its balance sheet (Reis, 2016). Central banks' monetary policy actions and subsequent stock market implications are discussed by various researchers (Thornton, 2006; Joyce et al., 2011; Savor and Wilson, 2014; Rey, 2015; Lima et al., 2016; Nakazono and Ikeda, 2016; Al-Jassar and Moosa, 2019). Discount rates and treasury yields are important variables used by central banks to implement their monetary policy. Central banks can change the supply of short-term or long-term treasury bonds that affect yield curves (Greenwood et al., 2016; Ihrig et al., 2018).

Central bank balance sheets have attained the focus of researchers during the last decade (Carpenter, 2013; Caballero and Farhi, 2018; Christensen et al., 2015; Del Negro and Sims, 2015; Woodford, 2016; Huther et al., 2017; Al-Jassar and Moosa, 2019). Contrasting the general perception that central bank balance sheet size became relevant to stock markets after the 2008 financial crisis (see, e.g. Bedikanli, 2020), this paper analyzes how the Fed's balance sheet, stock market and US gross domestic product (GDP) developed over the last 100 years, exploring a potential long-term relation. It is conspicuous how major central banks raised their balance sheets after the 2008 financial crisis and that a central bank's balance sheet can affect stock markets. A less-researched question is as follows: Is there a long-term relation between a central bank's balance sheet size and stock market return?

Asset-pricing literature investigates whether a variable relates to future stock market performance (e.g. Cowles, 1933; Fama and Schwert, 1977; Campbell, 1987; Campbell and Shiller, 1988b, 1998; Patelis, 1997; Goyal and Welch, 2008; Rapach and Zhou, 2013; Cieslak et al., 2015). Market return predictability is one of the most researched finance literature topics (Cochrane, 2011; Cieslak and Povala, 2014; Al-Jassar and Moosa, 2019). This paper's main hypothesis is as follows:

H1. There is a long-term positive relation between the Fed's balance sheet size and future market performance.

Specifically, when the Fed's balance sheet size increases compared to asset market wealth, this suggests a better stock market performance in the future. This hypothesis and the research question are important for macroprudential and monetary policymakers, given that the Fed's balance sheet has regained the central stage in the ongoing economic distress in 2020 (Al-Jassar and Moosa, 2019; Bedikanli, 2020).

\section{Data, variables and methodology}

\subsection{Databases}

I collected the data from the Federal Reserve's balance sheet for the last 100 years from the FRASER database, which is a digital library of US economic, financial and banking history,
Stock markets and Fed's balance sheet 
JES

49,2

\section{2}

\subsection{Variables}

3.2.1 Independent variables. Monthly MktRet is available from the CRSP database for 19262015. Kyindno 1000080 (1000081) is for value-weighted (equally-weighted) market return containing NYSE, AMEX and NASDAQ indices. I construct excess market return using the one-month T-bill rate as the proxy for risk-free return [2], $R f_{t}$ (e.g. Goyal and Welch, 2008). It is used to calculate value (equally) weighted excess market returns, $r_{\mathrm{vw}}{ }^{e}\left({ }_{\mathrm{ew}}{ }^{e}\right)$. I choose nominal market returns as opposed to real market returns to construct an equity premium because the effect of inflation for market return and for risk-free return will cancel out.

3.2.2 Dependent variables. The main explanatory variable is the Fed's balance sheet size ratio deflated by asset market wealth (FAMC), as described in Table 1, panel A. The second variable is $\Delta \mathrm{FA}$, i.e. a simple change in the Fed's total assets. A record of the Federal Reserve's balance sheet is available in the FRASER database from 1915 onwards, in various frequencies, e.g. weekly, monthly and annually. The end of period market

Panel A. Data, main variable definitions and source of data, 1926-2015

\begin{tabular}{llll} 
Variable & Definition & Source & Explanation \\
\hline FAMC & $\ln \left(1+\left(\frac{\mathrm{FA}_{t}}{\mathrm{MC}_{t}}\right)\right)$ & $\begin{array}{l}\text { CRSP and } \\
\text { FRASER }\end{array}$ & $\begin{array}{l}\text { The ratio of the Fed's total assets (FA) and the } \\
\text { market cap (MC) } \\
\text { TFA }\end{array}$ \\
$\ln \left(1+\frac{\mathrm{FA}_{t}-\mathrm{FA}_{t-1}}{\mathrm{FA}_{t-1}}\right)$ & FRASER & The change in the Fed's total assets \\
$r_{t}^{e}$ & $\ln \left(\frac{P_{t}+D_{t}}{P_{t-1}}\right)-\left(1+R f_{t}\right)$ & CRSP & Excess market return
\end{tabular}

Panel B. Summary statistics, monthly (1926:07-2015:12)

\begin{tabular}{lccccc} 
Variable & Mean & Std. Dev & Min & Max & $\varphi$ \\
\hline$\Delta$ FA & 0.01 & 0.03 & -0.15 & 0.40 & 0.032 \\
FAMC & 0.21 & 0.16 & 0.050 & 0.67 & $0.996^{* * *}$ \\
Infl & 0.002 & 0.005 & -0.021 & 0.057 & $0.483^{* * *}$ \\
RREL & -0.000 & 0.008 & -0.043 & 0.045 & $0.906^{* * * *}$ \\
TermS & 0.009 & 0.010 & -0.027 & 0.033 & $0.973^{* * *}$ \\
Total fed assets & 432,284 & - & 4,716 & $4,509,462$ & - \\
Market cap & $3,378,015$ & - & 12,392 & $19,926,464$ & - \\
dp & -3.358 & 0.456 & -4.502 & -1.977 & $0.994^{* * * *}$ \\
ep & -2.725 & 0.415 & -4.818 & -1.761 & $0.991^{* * *}$ \\
de & -0.632 & 0.331 & -1.244 & 1.379 & $0.991^{* * *}$ \\
$r_{\mathrm{vw}}{ }_{e}$ & 0.010 & 0.045 & -0.340 & 0.33 & $0.088^{* * *}$ \\
$r_{\mathrm{ew}}$ & 0.006 & 0.057 & -0.379 & 0.510 & $0.188^{* * *}$
\end{tabular}

Note(s): The first two rows in panel b relate to the Fed's total assets: (1) change in the Fed's total assets, $\Delta \mathrm{FA}$, and (2) Fed assets to market cap, FAMC. The next two rows are the change in consumer price index, Infl, and relative short-term treasury bill rate, RREL. The following row is term spread, TermS, from the Fred database, available during 1953:04-2015:12. The next two rows present total Fed assets and total market cap in millions of dollars. The three rows that come next are dividend price (dp), earning price (ep) and dividend payout (de)

Table 1.

Variables and summary statistics ratio. The last two rows present excess value weighted, $r_{\mathrm{vw}}{ }^{e}$, and excess equally weighted, $r_{\mathrm{ew}}{ }^{e}$, market returns, where $R_{f t}$ is the one-month treasury rate. The last column presents autocorrelation coefficients, $\varphi$ $* * *, * *$ and $*$ represent statistical significance levels at 1,5 and $10 \%$, respectively 
capitalization is available from 1926 in the CRSP database. I use monthly, quarterly and annual data of the Fed's total assets for 1926-2015 to match the CRSP database's timing. To show how the Fed's total assets relate to stock markets during the last 100 years, I add NYSE market return during 1916-2015 from Goetzmann et al. (2001) to the CRSP market return during 1926-2015.

I define Term spread, TermS, as the difference between the long-term yield $\left(L T_{-} y\right)$, i.e. a tenyear maturity treasury bond yield (GS10) and the short-term yield, $S T \_y$, i.e. one-year maturity treasury bill rate (GS1) (Campbell, 1987; Wheelock and Wohar, 2009). Similarly, the relative short-term treasury rate, RREL, is the relative difference between the three-month treasury bill rate (TB3M) and the past 12-month average of the three-month treasury bill rate. The threemonth treasury bill rate is available for the period 1934:01 and ten years, and one-year maturity yields are available the period 1953:04 in the Fred database. The three-month treasury bill rate during 1926:07-1933:12 is from the CRSP US Treasury and Inflation series (CTI).

I define inflation as the rate of change in the consumer price index, collected from the CRSP database. I use a one-month lag in inflation as argued by the existing literature because the data on inflation are published in the following month (e.g. Goyal and Welch, 2008). Moreover, I use the data from Robert Shiller's website and define the dividend to price, dp, (earnings to price, ep) ratio by taking the difference between the log of dividends (earnings) and the log of prices (e.g. Maio, 2013). These dividends and earnings are from the S\&P corporation and are taken during 1926-2015. Similarly, the dividend payout (de) is defined as the log difference between the log dividends and the log earnings. I choose control variables that are most relevant from a very diverse list of controls that can be employed (e.g. Fama and Schwert, 1977; Patelis, 1997). Table 1 provides summary statistics and autocorrelation coefficients of variables used. All the variables are converted to a logarithmic form following the literature (Cieslak et al., 2015).

I follow Ang and Bekaert (2007) and conduct a unit root test that is the Phillips and Perron (1988) test for the estimate regression $x_{t}=\alpha+\rho x_{t-1}+\mu_{t}$ under the null $x_{t}=P_{t-1}+\mu_{t}$. The critical values corresponding to $p$-values of $0.01,0.025,0.05$ and 0.10 are $-3.46,-3.14$, -2.88 and -2.57 , respectively. Although the time series of FAMC is persistent, it depicts stationarity during the periods 1941-2015 and 1953-2015. Conversely, FAMC is nonstationary during the full sample 1926-2015. For example, during the sample period 1953-2015, for the Phillips-Perron unit root test for the single mean, the values of Tau (probability) are $-3.80(0.0032)$ and $-3.77(0.0035)$ for lags 0 and 1 . This mixed evidence of stationarity suggests that results from regression analysis should be interpreted with caution.

\subsection{Methodology}

I run univariate predictive regression as in Fama and French (1988):

$$
z_{t+k}=\alpha+\beta_{k} \xi_{t}+\epsilon_{t}+_{k, k}
$$

where $\beta_{k}$ represents the coefficient of predicting variable $\xi$. Independent variables, $\xi_{t}$, represent FAMC, $\Delta$ FA, RREL, Infl, ep, dp or TermS, etc. Similarly, continuously compounded value-weighted (equally weighted) market return $r_{\mathrm{vw}}\left(r_{\mathrm{ew}}\right)$ and excess value-weighted (equally weighted) market return $r_{\mathrm{vw}}{ }^{e}\left(r_{\mathrm{ew}}{ }^{e}\right)$ are used as dependent variables, $z_{t+k}$. For $k$-period ahead prediction, variable $z_{t+k}$ is defined as $z_{t+k}=(1 / k)\left(r_{t+1}+\ldots+r_{t+k}\right)$. To mitigate the concern of small sample bias by Stambaugh (1999), I follow Ang (2012) and use GMM operationalization for regression Eq. (1). The asymptotic distribution of parameters $\theta=\left(\alpha \beta_{k}\right)^{\prime}$ is given as follows:

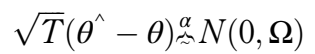

Stock markets and Fed's balance sheet 


$$
\Omega=Z_{0}^{-1} S_{0} Z_{0}^{-1}, Z_{0}=E\left(x_{t} x_{t}^{\prime}\right)
$$

where $x_{t}=\left(1 \mathrm{FAMC}_{t}\right)^{\prime}$ or $x_{t}=\left(1 \Delta \mathrm{FA}_{t}\right)^{\prime}$. To get Newey and West (1986) estimates with $k$ lags, $S_{0}$ is defined as $S_{\hat{0}}=k \sum_{j=-k}^{k} \frac{k-|j|}{k} C(j)$, where $C(j)$ is given as follows

$$
C(j)=\frac{1}{T} \sum_{t=j+1}^{T}\left(\omega_{t}+{ }_{k} \omega_{t+k-j^{\prime}}\right), \text { where } \omega_{t+k=\epsilon_{t}+k}, k x_{t} .
$$

Furthermore, I mitigate the concerns of heteroscedasticity by conducting the White (1980) test of heteroscedasticity. Failing to reject the null of homoscedasticity, I do not report these results. As the GMM system in this work is exactly identified, and the results are identical to those of OLS, I do not report results based on OLS. I report GMM estimates using one lag and annualize the slope coefficient, $\beta_{k}$, by multiplying with $12 / K$ following Maio (2013).

4. Central bank balance sheets, stock markets and the transmission mechanism Greenwood et al. (2016) argue that central banks influence relative yields on safe claims by changing the overall supply of safe, short-term and long-term claims, affecting the yield curve. Moreover, increasing the supply of long-term US Government securities puts downward pressure on long-term interest rates that improve liquidity and availability of cheaper long-term credit (as visible in Figure 1 panel B (left). Reis (2016) mentions that during FOMC statements on March 18, 2009 (QE 1), November 3, 2010 (QE 2) and September 21, 2011 (QE 3), the Federal Reserve announced the purchase of long-term securities of $\$ 300 \mathrm{bn}$, $\$ 600$ bn and $\$ 400$ bn (against selling short-term securities of $\$ 400$ billion). Furthermore, after the QE 1 program on March 18, 2009, the Federal Reserve's total purchases in mortgagebacked securities and agency debt were $\$ 1.25$ tn and $\$ 200$ bn, respectively.

Figure 1 shows how the Fed's balance sheet relates to stock market performance during the last 100 years, and panel A (right) in Figure 1 presents the annual change in the Fed's balance sheet size along with changes in the stock market index during 1916-2015. It provides graphical support to the research question and the hypothesis of this paper, i.e. there is a long-term positive relation between the Fed's balance sheet size and future market return. Panel B (right) Figure 1 presents FAMC ratio along with market return. It also presents the historical mean and minimum values of FAMC. The figure shows how stock markets historically reacted whenever FAMC approached its historical minimum value. In total, three times in history FAMC approached its minimum value, (1) the Great Depression of the 1930s, (2) the dot-com bubble of 2000 and (3) the great financial crisis of 2008.

Furthermore, an increase (decrease) in a central bank's balance sheet size signals an expansionary (deflationary) monetary policy that leads to an increase (decrease) in asset prices following the monetary policy transmission channel (e.g. Alcidi and Gros, 2011; ECB, 2019). Through the wealth channel, an increase in asset prices increases aggregate wealth, and Ludvigson and Steindel (1998) show that an increase in wealth leads to an increase in consumption (C). An increase in aggregate consumption implies future economic growth and, thus, higher future expected stock market return (FA $\uparrow \rightarrow \mathrm{MC} \uparrow \rightarrow C \uparrow \rightarrow E$ (return) $\uparrow$ ).

Similarly, if a change in the Fed's balance sheet size signals a changing monetary policy and the change in market cap signals changing asset prices, then comparing these two in the form of FA/MC can provide useful signals about the future state of the economy and stock markets. An increase in FAMC implies higher expansionary actions compared to asset price increases. A decrease in FAMC implies lower expansionary action compared to asset price changes. Moreover, given the wealth channel, a positive change in FAMC suggests even higher consumption and higher expected future stock return and vice-versa $\left(\frac{\mathrm{FA}}{\mathrm{MC}} \uparrow \rightarrow C\right.$ $\uparrow \uparrow \rightarrow E($ return $) \uparrow \uparrow)$. In this paper, I refine the transmission mechanism of monetary policy and 
Stock markets and Fed's
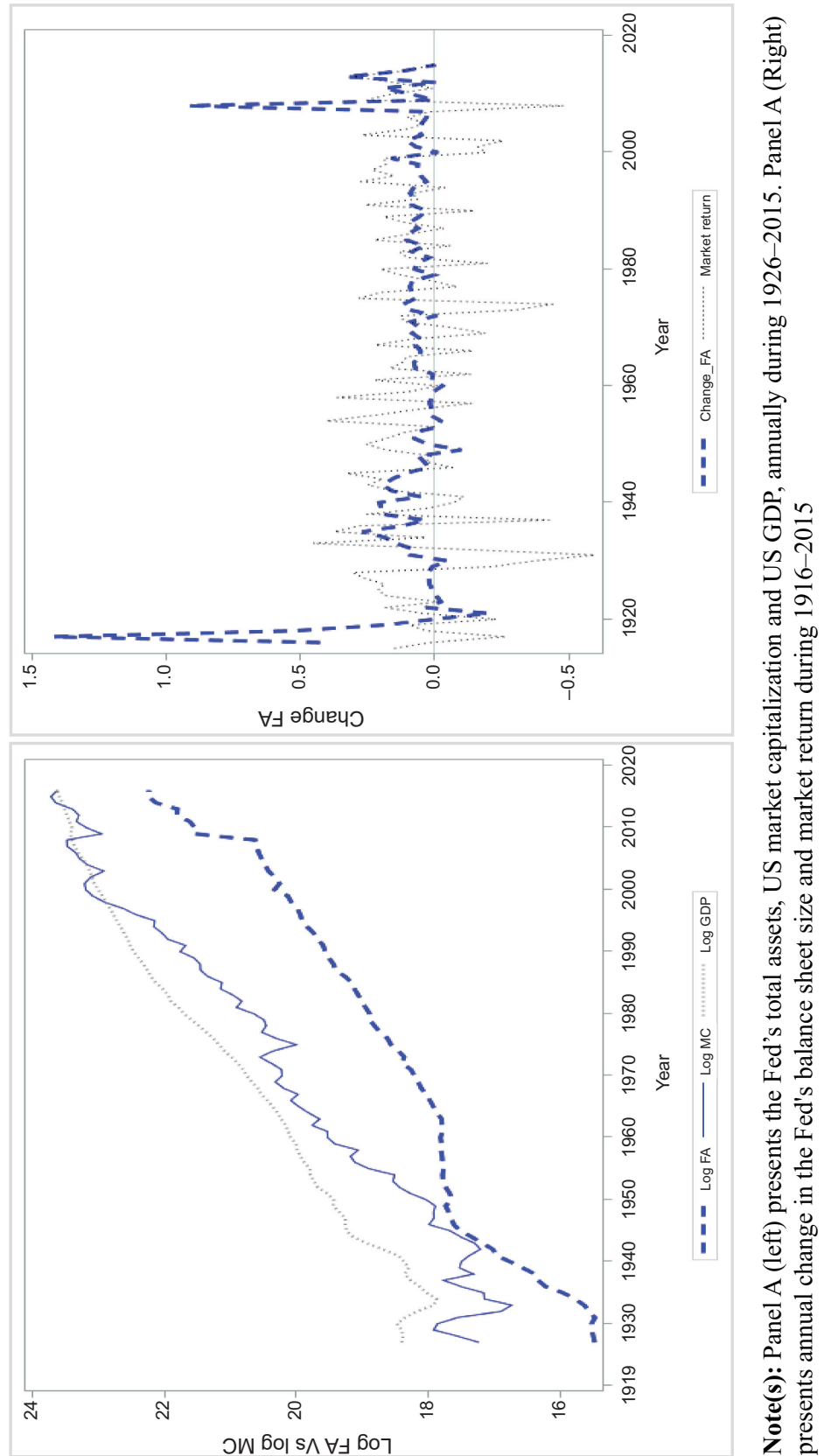

265

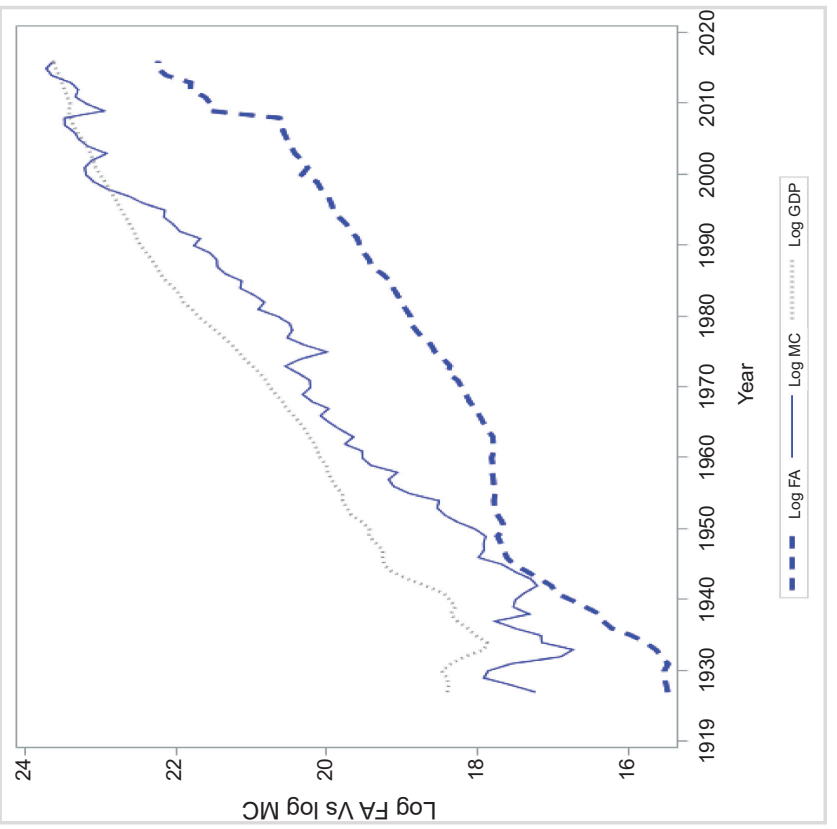

Figure 1.

Fed's balance sheet size, 1916-2015 
JES

49,2

266
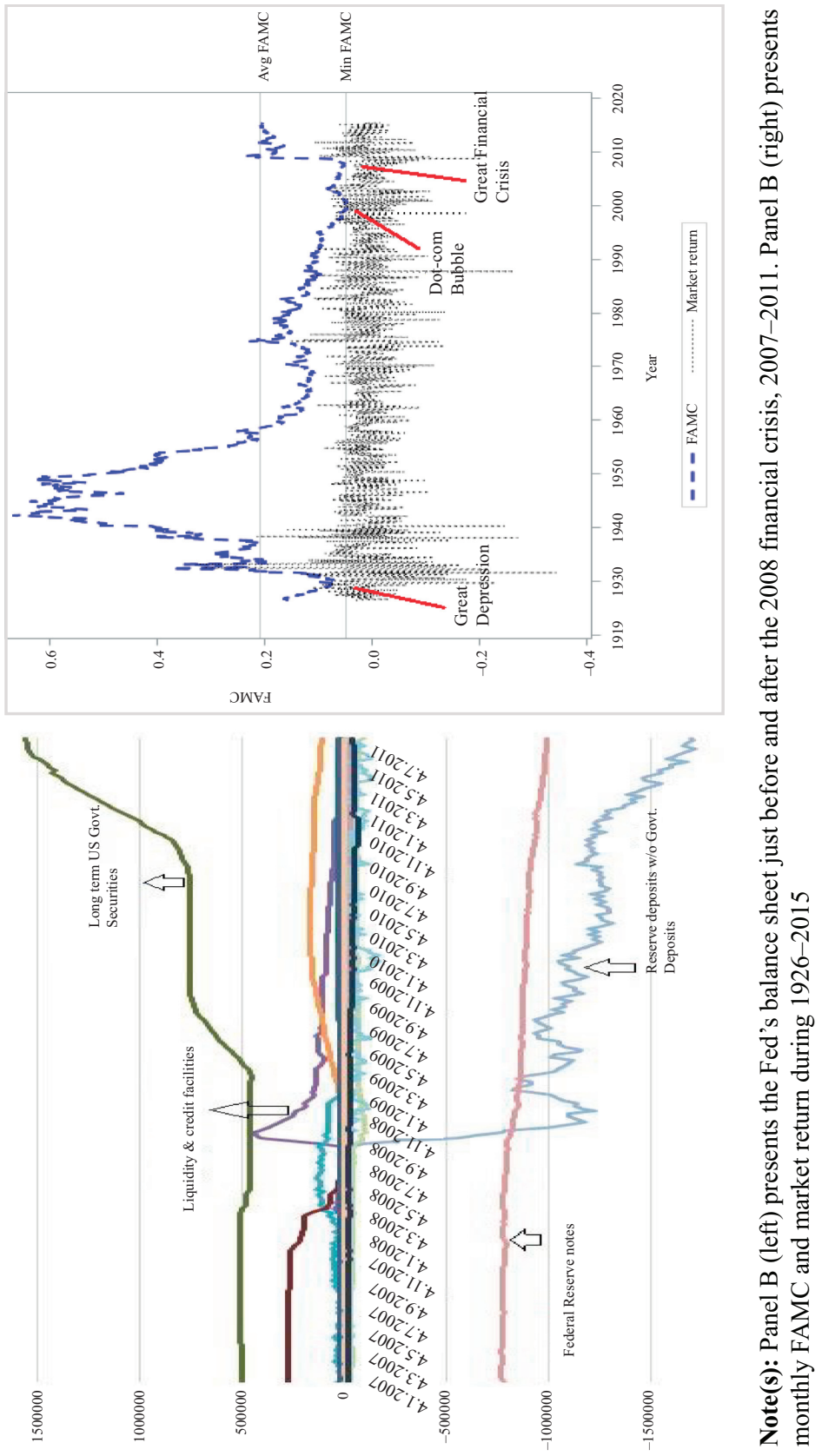

Figure 1. 
use the wealth channel's intuition to investigate a potential long-term relation between the size of a central bank's balance sheet and future stock market performance.

\section{Empirical results}

5.1 Return predictability by FAMC

Panel $\mathrm{B}$ and $\mathrm{C}$ of Table 2 present FAMC predictive evidence on a monthly horizon during the period 1926:07-2015:12 and 1953:04-2015:12. These tables report how the predictive power of FAMC withstands the presence of control variables. To investigate long-term predictive power of FAMC, I use annual data during 1926-2015, and panel A in Table 2 presents these findings. Specifically, in multivariate regression between FAMC, earning price and term spread, $\beta$ and $t$-stats for FAMC are 0.293 and 2.30 with $R^{2}$ of $9.96 \%$.

Panel B in Table 2 shows that in the univariate predictive regression with value-weighted excess market return, the explanatory variable (FAMC) has $\beta$ and $t$-stats of 0.341 and 3.09 with $R^{2}$ of $0.68 \%$. In multivariate regression between FAMC, RREL, Infl and dividend-price, $\beta$ and $t$-stats for FAMC are 0.373 and 2.28 with $R^{2}$ of $1.25 \%$. Moreover, the multivariate regression between FAMC, Infl and RREL, $\beta$ estimate and $t$-stats for FAMC are 0.359 and 3.01 with $R^{2}$ of $1.24 \%$.

\begin{tabular}{|c|c|c|c|c|c|c|}
\hline \multicolumn{6}{|c|}{ Panel A. Predictive evidence of FAMC, annual (1926-2015) } & $R^{2}(\%)$ \\
\hline $\begin{array}{l}r_{v w}^{e} \\
0.105(0.68)\end{array}$ & \multicolumn{2}{|c|}{$0.293^{* *}(2.30)$} & \multicolumn{2}{|c|}{$0.046(0.90)$} & $0.516^{* * * *}(2.84)$ & 9.96 \\
\hline $\begin{array}{l}r_{e w}^{e} \\
-0.069(-0.32)\end{array}$ & \multicolumn{2}{|c|}{$0.506^{* * * *}(2.72)$} & \multicolumn{2}{|c|}{$-0.01(-0.14)$} & $0.659 * * *(2.60)$ & 10.22 \\
\hline \multicolumn{6}{|c|}{ Panel B. Predictive power of FAMC, monthly (1926:07-2015:12) } & $R^{2}(\%)$ \\
\hline $\begin{array}{l}-0.010(-0.36) \\
-0.033(-0.11) \\
-0.005(-0.11) \\
-0.013(-0.45) \\
-0.026(-0.08)\end{array}$ & $\begin{array}{l}0.341 * * *(3.09) \\
0.373 * *(2.28) \\
0.359 * * *(3.01) \\
0.352 * * *(3.19) \\
0.348^{* * *}(2.07)\end{array}$ & & $\begin{array}{l}781 * *(-2.44) \\
788 * *(-2.33) \\
143 * * *(-2.65)\end{array}$ & $\begin{array}{l}-4.097(-0.85) \\
-4.056(-0.83)\end{array}$ & $-0.008(-0.10)$ & $\begin{array}{l}0.68 \\
1.25 \\
1.24 \\
1.13 \\
0.68\end{array}$ \\
\hline
\end{tabular}

Panel C. Predictive power of FAMC, monthly (1953:04-2015:12)

\begin{tabular}{|c|c|c|c|c|c|c|}
\hline$\alpha$ & FAMC & RREL & Infl & TermS & $\mathrm{dp}$ & $R^{2}(\%)$ \\
\hline$-0.054(-0.36)$ & $0.826 * * *(2.98)$ & & & & & 1.02 \\
\hline $0.152(0.61)$ & $0.809 * *(2.07)$ & $-4.296^{* *}(-2.27)$ & $-9.663(-1.48)$ & & $0.045(0.74)$ & 2.45 \\
\hline$-0.055(-1.02)$ & $0.853 * * *(3.02)$ & $-3.507(-1.55)$ & $-6.942(-1.11)$ & $1.879(0.85)$ & & 2.48 \\
\hline$-0.022(-0.09)$ & $0.798 * *(2.51)$ & & & & $0.008(0.13)$ & 1.03 \\
\hline
\end{tabular}

Note(s): Table 2 presents results of predictive regression $z_{t+k}=\alpha+\beta_{k} \xi_{t}+\epsilon_{t}+k, k$. The four independent variables, $\xi_{t}$, in all regressions are the following: (1) FAMC, i.e. ratio of Fed assets to market cap, (2) change in consumer price index, Infl, (3) relative rate of return, relative short-term treasury rate (RREL), and (4) dividend to price ratio, dp. There are two dependent variables, $z_{t+1}$ : (1) excess value-weighted market return $r_{\mathrm{vw}}{ }^{e}$ and (2) excess equally weighted market return, $r_{\mathrm{ew}}^{e}$. Newey and West (1986) standard errors are corrected for autocorrelation and heteroscedasticity using one lag. ***, ** and * represent statistical significance levels at 1 , 5 and $10 \%$, respectively. All variables used are in natural logs. Coefficients are annualized by multiplying with 12 and $R^{2}$ are in percentages

Everything in Panel C is the same as in panel B except (1) it presents results of the recent sub-sample 1953:042015:12 and (2) it contains an additional control, term spread. Panels B and C only report results for valueweighted market return without year fixed effects to save space, as the results for equally weighted market return with and without year fixed effects are materially the same
Stock markets and Fed's balance sheet

267 
JES

49,2

268

Moreover, in panel $\mathrm{C}$ of Table 2 for monthly value-weighted excess market return during 1953-2015, $\beta$ and $t$-stats for FAMC are 0.826 and 2.98 with $R^{2}$ of $1.02 \%$. In multivariate regression between FAMC, RREL, Infl and term spread, $\beta$ and $t$-stats for FAMC are 0.853 and 3.05 with $R^{2}$ of $2.48 \%$. In regression for equally weighted excess market return as the dependent variable, $\beta$ and $t$-stats for FAMC are 0.938 and 2.44 with $R^{2}$ of $1.18 \%$.

Collectively, short-term and long-term evidence of return predictability offered by FAMC is statistically significant and withstands the presence of main control variables, different sample-periods, different data frequency and changing dependent variables from valueweighted to equally weighted or excess market return to full market return.

\subsection{Robustness}

5.2.1 Long-horizon predictability and bootstrapping. I perform long-horizon, from 1 to 60 months ahead, regressions to assess the predictive power of FAMC for future excess market returns. Due to the poor small-sample properties of the asymptotic $t$-stats for longhorizon regressions (Nelson and Kim, 1993), I also present $t$-statistics based on Newey and West (1986) and $t$-statistics based on a bootstrap experiment with 10,000 replications. The Newey-West standard errors are calculated using $K$ lags, i.e. the predicting horizon of each regression.

Panel A of Table 3 presents these results. Lines 2 and 3 report Newey-West $t$-statistics and $t$-statistics from the bootstrap experiment with 10,000 replications. Coefficients of FAMC decline as the horizon increases, ranging from $0.881(K=3)$ to $0.301(K=60)$ for valueweighted market return and $0.928(K=3)$ to $0.201(K=60)$ for equally weighted market return. On all horizons, these estimates are statistically significant at standard significance levels based on Newey-West $t$-statistics and $t$-statistics from the bootstrap experiment with 10,000 replications. $R^{2}$ for each regression of FAMC increases from $2.93 \%(K=3)$ to $33.37 \%$ $(K=36)$ and drops to $11 \%(K=60)$.

5.2.2 Various sub-samples within the full-sample 1926-2015. I use ten different sample periods for multiple reasons. The full-sample offers the complete picture; the sample over the period 1926-2007 analyzes how the 2008 financial crisis affects the results. It also mitigates concerns of structural break during 2008 financial crisis; the sample over the period 19262000 offers the effect of the dot-com bubble; many classical papers of return predictability are from 1926 to 1990 and the policy of lowering interest rates started after this period; interest rates peaked before 1926-1980; 1941-2005 and 1941-2015 to analyze postGreat Depression results with and without the 2008 financial crisis also because long-term yield from CRSP data starts from 1941; 1953-2015 is the postwar period also because term spread from the Fred database is available from 1953:04 onward; lastly, 1971-2015 and 1981-2015 are the most recent sample periods. The predictive power offered by FAMC remains strong during all the sample periods tested.

5.2.3 3 Residual analysis and structural break test. Residuals from simple linear regression are analyzed where FAMC is the independent variable and the excess market return is the dependent variable. These residuals do not point to any specific pattern or nonlinearity. Moreover, results from the lack of fit test show that linear terms are statistically significant ( $F$-value of 5.85 and respective $p$ value of 0.017 ) whereas nonlinear terms are not. Moreover, panel A and B in Figure 1 show time series of dependent and independent variables during 1926-2015. Panel B indicates a potential structural break around 2008 financial crisis. To assess potential structural break around the 2008 financial crisis, I conduct Chow test of structural change for years 2007, 2008, 2009 and 2010. Results confirm a structural break after the year 2007 as anticipated. To mitigate the potential impact of this structural break on these regression results' reliability, I conduct a similar regression analysis using data before 2007, i.e. prefinancial crisis data (see, e.g. Bedikanli, 2020). Results for prefinancial crisis data from regression analysis remain materially the same (unreported). 


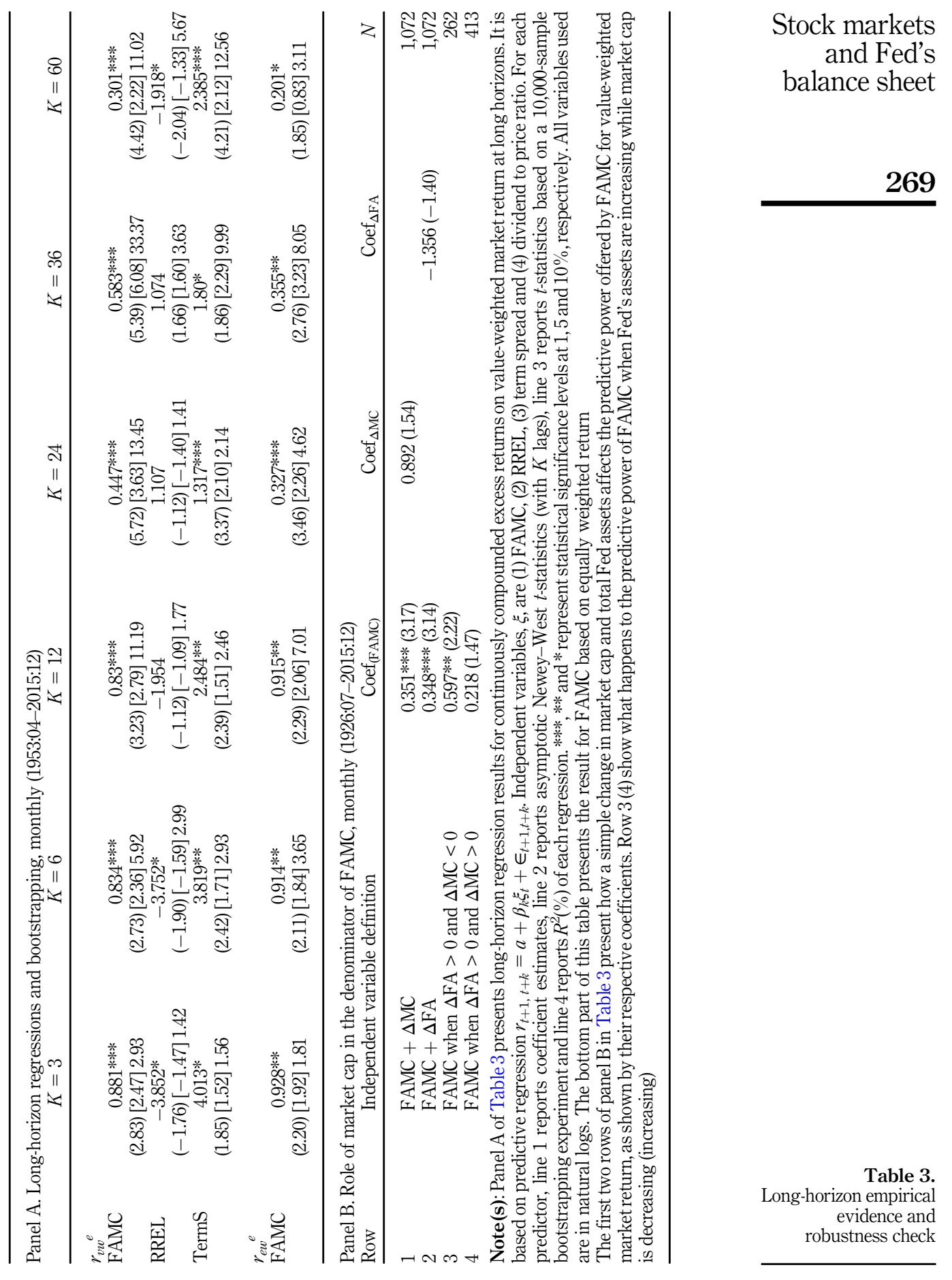


JES

49,2

5.2.4 Controlling for change in FA or change in MC. First, I control for proxies related to market cap such as dividend price and earning price. Additionally, I analyze how the presence of simple market cap affects predictability offered by FAMC, as in below equation. I also analyze what happens to the predictive power of FAMC in months during which market cap is increasing (decreasing), the Fed's total assets are increasing (decreasing), lastly when the Fed's assets are increasing and at the same time market cap is increasing (decreasing) [3] i.e. the predictive power of when (1), (2), (3), (4), (5) and lastly (6). Due to parsimony, I report few but representative results for value-weighted excess market return during 1926:07-2015:12 in panel B of Table 3.

$$
r_{t}=\alpha+\beta\left(\mathrm{FAMC}_{t-1}\right)+\gamma\left(\mathrm{MC}_{t-1}\right)+\epsilon_{t},
$$

For example, in panel B of Table 3, row 3 shows that when the Fed's total assets increase and market cap decreases, the impact of FAMC ratio on future market return is statistically significant. However, in row 4 when $\mathrm{FA}$ increases and $\mathrm{MC}$ also increases, the impact of FAMC on future market return is statistically nonsignificant. This confirms the intuition that the Fed's total assets are higher concerning market capitalization implies good future stock market performance and vice versa.

5.2.5 Additional control variables. Additional control variables such as dividend-payout ratio, industrial production, GDP growth or credit spread also do not decisively change these results (unreported).

5.2.6 Controlling for outliers: bubbles and crashes. I also controlled for potential outliers when the market is extremely low or high, such as during (1) the great crashes of 1930-1931, 1974, 1987, 2000 and 2008 or (2) bubbles such as 1926-1928, 1999 and 2007. The coefficient of FAMC remains positive and largely unchanged after controlling for these outliers (unreported).

\section{Economic significance and concluding remarks}

Although stock market implications of various monetary policy tools are well researched, the impact of a central bank's balance sheet size on stock markets became an important research question after 2008 financial crisis. This paper presents the empirical evidence of a positive relation between the Fed's balance sheet size and stock market performance during the last 100 years. The Fed's total assets to market cap ratio provides robust evidence of market return predictability on various sample periods and horizons.

This relation can be explained through the wealth channel of monetary policy transmission. Recently, given zero lower bound, policymakers have increasingly relied upon "unconventional monetary policy" and QE, in which central banks focused on maturity transformation and changing the supply of safe assets using their balance sheet. Therefore, an increase in the Fed's balance sheet size compared to asset market wealth suggests that the extent of expansionary monetary policy is greater than the change in asset market wealth (i.e. positive change in FAMC). Irrespective of its extent, an expansionary monetary policy should increase agents' wealth, leading to increased consumption (Ludvigson and Steindel, 1998). This increased consumption leads to better future economic performance and thus higher future expected return.

The main implication of the empirical relation between a central bank's balance sheet size and stock market performance is that policymakers should avoid a severe imbalance between the balance sheet size of a central bank and asset market wealth. Future research should focus on (1) What is the theoretical framework behind this relation? (2) How does it relate to various definitions of aggregate money supply, such as monetary base or inside money supply? (3) How do other major central banks' balance sheets relate to their respective stock markets? (4) How does the Fed's balance sheet change affects volatility, risk and the pricing of derivative securities. Finally, (5) what is the impact of COVID-19 related large asset purchases on stock markets. 


\section{Notes}

1. Available at https://www.federalreserve.gov/monetarypolicy/policytools.htm

2. Thanks to http://mba.tuck.Dartmouth.edu/pages/faculty/ken.french/

3. i.e. the predictive power of FAMC when (1) $\Delta \mathrm{MC}>0$, (2) $\Delta \mathrm{MC}<0$, (3) $\Delta \mathrm{FA}>0$ (4) $\Delta \mathrm{FA}<0$, (5) $\Delta \mathrm{FA}>0$ and $\Delta \mathrm{MC}>0$ and lastly (6) $\Delta \mathrm{FA}>0$ and $\Delta \mathrm{MC}<0$.

\section{References}

Adrian, T. and Shin, H.S. (2009), "Prices and quantities in the monetary policy transmission mechanism”, Federal Reserve Bank of New York Staff Report, p. 396, available at SSRN: https:// ssrn.com/abstract $=1483825$.

Al-Jassar, S.A. and Moosa, I.A. (2019), "The effect of quantitative easing on stock prices: a structural time series approach", Applied Economics, Vol. 51 No. 17, pp. 1817-1827.

Alcidi, C.A. (2011), "Great recession versus great depression: monetary, fiscal and banking policies", Journal of Economic Studies, Vol. 38 No. 6, pp. 673-690.

Alexius, A. and Sp, D. (2018), "Stock prices and GDP in the long run", Journal of Applied Finance and Banking, Vol. 8 No. 4, pp. 107-126.

Ang, A. (2012), "Predicting dividends in log-linear present value models", Pacific-Basin Finance Journal, Vol. 20 No. 1, pp. 151-171, doi: 10.1016/j.pacfin.2011.08.005.

Ang, A. and Bekaert, G. (2007), "Stock return predictability: is it there?", Review of Financial Studies, Vol. 20 No. 3, pp. 651-707.

Bedikanli, M. (2020), "Quantitative easing and US stock prices: a study on unconventional monetary policy and its long-term effects on stocks", (Dissertation), available at: http://urn.kb.se/resolve? urn= urn:nbn:se:umu:diva-167940.

Billi, R.O. and Vredin, A. (2014), "Monetary policy and financial stability-a simple story", Sveriges Riksbank Economic Review, Vol. 2, pp. 1-22.

Bjørnland, H.C. and Leitemo, K. (2009), "Identifying the interdependence between US monetary policy and the stock market", Journal of Monetary Economics, Vol. 56 No. 29, pp. 275-282.

Bordo, M.D. and Jeanne, O. (2002), Boom-busts in Asset Prices, Economic Instability, and Monetary Policy, No. w8966, National Bureau of Economic Research Publications, Cambridge, MA.

Borio, C. and Drehmann, M. (2009), "Financial instability and macroeconomics: bridging the gulf", Twelfth Annual International Banking Conference, The International Financial Crisis: Have the Rules of Finance Changed.

Brunnermeier, M.K. (2009), "Deciphering the liquidity and credit crunch 2007-2008", The Journal of Economic Perspectives, Vol. 23 No. 1, pp. 77-100.

Caballero, J.R. and Farhi, E. (2018), "The safety trap”, The Review of Economic Studies, Vol. 85 No. 1, pp. 223-274

Campbell, J.Y. (1987), "Stock returns and the term structure", Journal of Financial Economics, Vol. 18 No. 2, pp. 373-399.

Campbell, J.Y. and Shiller, R.J. (1988b), "Stock prices, earnings, and expected dividends", The Journal of Finance, Vol. 43 No. 3, pp. 661-676.

Campbell, J. and Shiller, R. (1998), "Valuation ratios and the long-run stock market outlook", Journal of Portfolio Management, Vol. 24 No. 2, pp. 11-26.

Carpenter, S.B., Ihrig, J.E., Klee, E.C., Quinn, D.W. and Boote, A.H. (2013), The Federal Reserve's Balance Sheet and Earnings: A Primer and Projections, No. 2013-01, Board of Governors of the Federal Reserve System (US), available at: https://www.federalreserve.gov/pubs/feds/2013/ 201301/201301abs.html.

Stock markets and Fed's balance sheet 
JES

49,2

Chen, Q., Filardo, A., He, D. and Zhu, F. (2016), "Financial crisis, US unconventional monetary policy and international spillovers", Journal of International Money and Finance, Vol. 67, pp. 62-81.

Christensen, J.H., Lopez, J.A. and Rudebusch, G.D. (2015), "A probability-based stress test of Federal Reserve assets and income”, Journal of Monetary Economics, Vol. 73, pp. 26-43.

Cieslak, A. (2018), "Short-rate expectations and unexpected returns in treasury bonds", Review of Financial Studies, Vol. 31 No. 9, pp. 3265-3306.

Cieslak, A. and Povala, P. (2014), "Expecting the fed", available at: https://ssrn.com/abstract=2239725.

Cieslak, A., Morse, A. and Vissing-Jorgensen, A. (2015), "Stock returns over the FOMC cycle", available at: $\mathrm{https}: / / \mathrm{ssrn} . \mathrm{com} /$ abstract $=2687614$.

Cochrane, J.H. (2011), "Presidential address: discount rates", The Journal of Finance, Vol. 66 No. 4, pp. 1047-1108.

Cowles, A. (1933), “Can stock market forecasters forecast?", Econometrica: Journal of the Econometric Society, pp. 309-324.

Curdia, V. and Woodford, M. (2011), "The central-bank balance sheet as an instrument of monetary policy", Journal of Monetary Economics, Vol. 58 No. 1, pp. 54-79.

Del Negro, M. and Sims, C.A. (2015), "When does a central bank's balance sheet require fiscal support?", Journal of Monetary Economics, Vol. 73, pp. 1-19.

Dotsey, M. (1998), "The predictive content of the interest rate term spread for future economic growth", FRB Richmond Economic Quarterly, Vol. 84 No. 3, pp. 31-51.

ECB (2019), "The monetary policy transmission mechanism”, available at: https://www.ecb.europa.eu/ mopo/intro/transmission/html/index.en.html.

Fama, E.F. and French, K.R. (1988), "Dividend yields and expected stock returns”, Journal of Financial Economics, Vol. 22 No. 1, pp. 3-25.

Fama, E.F. and Schwert, G.W. (1977), “Asset returns and inflation”, Journal of Financial Economics, Vol. 5 No. 2, pp. 115-146.

FRASER (2019), FRASER, available at: https://fraser.stlouisfed.org/about/.

FRED (2019), Board of Governors of the Federal Reserve System, M1 Money Stock, Federal Reserve Bank of, St. Louis, available at: https://fred.stlouisfed.org/series/M1.

Gambacorta, L., Hofmann, B. and Peersman, G. (2014), "The effectiveness of unconventional monetary policy at the zero lower bound: a cross-country analysis", Journal of Money, Credit, and Banking, Vol. 46 No. 4, pp. 615-642.

Goetzmann, W.N., Li, L. and Rouwenhorst, K.G. (2001), Long-term Global Market Correlations, No. w8612, National Bureau of Economic Research.

Goyal, A. and Welch, I. (2008), "A comprehensive look at the empirical performance of equity premium prediction”, Review of Financial Studies, Vol. 21 No. 4, pp. 1455-1508.

Greenwood, R., Hanson, S.G. and Stein, J.C. (2016), "The Federal Reserve's balance sheet as a financialstability tool", Designing Resilient Monetary Policy Frameworks for the Future, Jackson Hole Symposium, Federal Reserve Bank of Kansas City.

Huther, J., Ihrig, J.E. and Klee, E. (2017), "The Federal Reserve's portfolio and its effect on interest rates", FEDS Working Paper No. 2017-075, available at: https://ssrn.com/abstract=3003049.

Ihrig, J.K. (2018), "Expectations about the federal Reserve's balance sheet and the term structure of interest rates", International Journal of Central Banking, Vol. 12 No. 2, pp. 341-391.

Joyce, M., Lasaosa, A., Stevens, I. and Tong, M. (2011), "The financial market impact of quantitative easing in the United Kingdom", International Journal of Central Banking, Vol. 7 No. 3, pp. 113-161.

Lima, L., Vasconcelos, C.F., Simão, J. and de Mendonça, H.F. (2016), "The quantitative easing effect on the stock market of the USA, the UK and Japan", Journal of Economic Studies, Vol. 43 No. 6, pp. 1006-1021. 
Ludvigson, S.C. and Steindel, C. (1998), "How important is the stock market effect on consumption?", FRBNY Economic Policy Review, Vol. 5 No. 2, pp. 29-51.

Maio, P. (2013), "The 'Fed model' and the predictability of stock returns", Review of Finance, Vol. 17, pp. 1489-1533.

Nakazono, Y. and Ikeda, S. (2016), "Stock market responses under quantitative easing: state dependence and transparency in monetary policy", Pacific Economic Review, Vol. 21 No. 5, pp. 560-580.

Nelson, C.R. and Kim, M.J. (1993), "Predictable stock returns: the role of small sample bias", The Journal of Finance, Vol. 48 No. 2, pp. 641-661.

Newey, W.K. and West, K.D. (1986), A Simple, Positive Semi-definite, Heteroskedasticity and Autocorrelation Consistent Covariance Matrix, National Bureau of Economic Research, Cambridge, Mass.

Patelis, A.D. (1997), "Stock return predictability and the role of monetary policy", The Journal of Finance, Vol. 52 No. 5, pp. 1951-1972.

Phillips, P.C. and Perron, P. (1988), "Testing for a unit root in time series regression", Biometrika, Vol. 75 No. 2, pp. 335-346.

Rapach, D. and Zhou, G. (2013), "Forecasting stock returns", Handbook of Economic Forecasting, Elsevier, Vol. 2, pp. 328-383.

Reis, R. (2016), "Funding quantitative easing to target inflation", available at: https://ssrn.com/ abstract $=2840702$.

Rey, H. (2015), Dilemma Not Trilemma: The Global Financial Cycle and Monetary Policy Independence, No. w21162, National Bureau of Economic Research Publications, Cambridge, MA.

Savor, P. and Wilson, M. (2014), “Asset pricing: a tale of two days”, Journal of Financial Economics, Vol. 113 No. 2, pp. 171-201.

Stambaugh, R.F. (1999), "Predictive regressions", Journal of Financial Economics, Vol. 54 No. 3, pp. 375-421.

Thornton, D.L. (2006), "When did the FOMC begin targeting the federal funds rate? What the verbatim transcripts tell us", Journal of Money, Credit, and Banking, Vol. 38 No. 8, pp. 2039-2071.

Wheelock, D.C. and Wohar, M.E. (2009), "Can the term spread predict output growth and recessions? A survey of the literature", Federal Reserve Bank of St. Louis Review, Vol. 91 No. 5, pp. 419-440.

White, H. (1980), "A heteroskedasticity-consistent covariance matrix estimator and a direct test for heteroskedasticity", Econometrica: Journal of the Econometric Society, Vol. 48 No. 4, pp. 817-838.

Woodford, M. (2016), Quantitative Easing and Financial Stability, No. w22285, National Bureau of Economic Research Publications, Cambridge, MA.

\section{Corresponding author}

Asif M. Ruman can be contacted at: asif.ruman@oulu.fi

\section{Stock markets and Fed's balance sheet}

